\title{
Peroxiredoxins: hidden players in the antioxidant defence of human spermatozoa
}

Cristian O'Flaherty ${ }^{1,2,3,4,5}$

\begin{abstract}
Spermatozoon is a cell with a precious message to deliver: the paternal DNA. Its motility machinery must be working perfectly and it should be able to acquire fertilizing ability in order to accomplish this mission. Infertility touches 1 in 6 couples worldwide and in half of the cases the causes can be traced to men. A variety of conditions such as infections of the male genital tract, varicocele, drugs, environmental factors, diseases, smoking, etc., are associated with male infertility and a common feature among them is the oxidative stress in semen that occurs when reactive oxygen species (ROS) are produced at high levels and/or when the antioxidant systems are decreased in the seminal plasma and/or spermatozoa. ROS-dependent damage targets proteins, lipids, and DNA, thus compromising sperm function and survival. Elevated ROS in spermatozoa are associated with DNA damage and decreased motility. Paradoxically, ROS, at very low levels, regulate sperm activation for fertilization. Therefore, the regulation of redox signaling in the male reproductive tract is essential for fertility. Peroxiredoxins (PRDXs) play a central role in redox signaling being both antioxidant enzymes and modulators of ROS action and are essential for pathological and physiological events. Recent studies from our lab emphasize the importance of PRDXs in the protection of spermatozoa as infertile men have significant low levels of PRDXs in semen and with little enzymatic activity available for ROS scavenging. The relationships between sperm DNA damage, motility and lipid peroxidation and high levels of thiol-oxidized PRDXs suggest the enhanced susceptibility of spermatozoa to oxidative stress and further support the importance of PRDXs in human sperm physiology. This review aims to characterize PRDXs, hidden players of the sperm antioxidant system and highlight the central role of PRDXs isoforms in the protection against oxidative stress to assure a proper function and DNA integrity of human spermatozoa.
\end{abstract}

Keywords: Reactive oxygen species, Oxidative stress, Sperm function, Male infertility

\section{Résumé}

Le spermatozoïde est une cellule qui porte un précieux message à délivrer : I'ADN paternel. La machinerie qui lui permet de se mouvoir doit fonctionner parfaitement et il doit avoir acquis ses capacités fécondantes afin d'accomplir sa mission. L'infertilité touche 1 couple sur 6 dans le monde, et dans la moitié des cas l'homme est en cause. Différentes conditions, telles que les infections du tractus génital masculin, la varicocele, les médicaments, les facteurs environnementaux, certaines maladies, la cigarette, etc., sont associées à l'infécondité masculine. Un trait commun à ces conditions est le stress oxydant dû sperme qui survient quand les dérivés actifs de l'oxygène (DAO) sont générés à des niveaux élevés et/ou quand les systèmes anti-oxydants sont diminués dans le plasma séminal (Continued on next page)

\footnotetext{
Correspondence: cristian.oflaherty@mcgill.ca

${ }^{1}$ The Research Institute of the McGill University Health Centre, Montréal,

Québec, Canada

${ }^{2}$ Department of Surgery (Urology Division), McGill University, Montréal,

Québec, Canada

Full list of author information is available at the end of the article
}

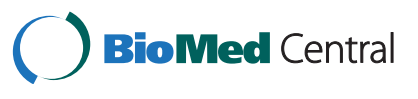

(c) 2014 O'Flaherty; licensee BioMed Central Ltd. This is an Open Access article distributed under the terms of the Creative Commons Attribution License (http://creativecommons.org/licenses/by/2.0), which permits unrestricted use, distribution, and reproduction in any medium, provided the original work is properly credited. The Creative Commons Public Domain Dedication waiver (http://creativecommons.org/publicdomain/zero/1.0/) applies to the data made available in this article, unless otherwise stated. 
(Continued from previous page)

et/ou dans les spermatozoïdes. Les dommages liés aux DAO touchent les protéines, les lipides, et l'ADN, ce qui compromet la fonction et la survie des spermatozoïdes. Des taux élevés de DAO dans les spermatozoïdes sont associés à une altération de l'ADN et à une diminution de leur mobilité. De façon paradoxale, les DAO à faibles concentrations contrôlent l'activation des spermatozoïdes lors de la fécondation. Ainsi la régulation de la signalisation redox dans le tractus génital masculin est essentielle pour la fécondité. Les peroxyrédoxines (PRDXs) jouent un rôle central dans la signalisation redox en étant à la fois des enzymes anti-oxydants et des modulateurs de l'action des DAO, se révélant ainsi essentielles aux processus pathologiques et physiologiques. Les travaux récents de notre laboratoire soulignent l'importance des PRDXs dans la protection des spermatozoïdes; en effet, les hommes inféconds ont des taux significativement abaissés de PRDXs dans le sperme, avec une faible activité enzymatique disponible pour l'élimination des DAO. Les relations entre l'altération de l'ADN des spermatozoïdes, leur mobilité et la péroxydation des lipides, et les niveaux élevés de PRDX dont les résidus thiols sont oxydés suggèrent une forte susceptibilité des spermatozoïdes au stress oxydant et soulignent l'importance des PRDXs dans la physiologie des spermatozoïdes. Cette revue a pour objectifs de caractériser les PRDXs, acteurs cachés du système anti-oxydant des spermatozoïdes, et de mettre en lumière le rôle des isoformes des PRDXs dans la protection contre le stress oxydant pour assurer une fonction correcte et de préserver l'intégrité de l'ADN des spermatozoïdes humains.

Mots clés: Dérivés actifs de l'oxygène, Stress oxydant, Fonction des spermatozoïdes, Infécondité masculine

\section{Introduction}

Infertility is an important human health problem that affects $\sim 15 \%$ of couples worldwide and the underlying cause in half of these cases can be traced to men [1]. Excessive levels in spermatozoa of reactive oxygen species (ROS) such as superoxide $\left(\mathrm{O}_{2}^{--}\right)$, hydrogen peroxide $\left(\mathrm{H}_{2} \mathrm{O}_{2}\right)$, nitric oxide $\left(\mathrm{NO}^{*}\right)$, the hydroxyl radical $\left(\mathrm{HO}^{*}\right)$ and peroxynitrite $\left(\mathrm{ONOO}^{-}\right)$, which are mostly produced in the sperm mitochondria [2] or by combination among them ( $\mathrm{NO}^{\circ}$ and $\mathrm{O}_{2}^{*-}$ produce $\mathrm{ONOO}-$ ) and become injurious by-products of cellular metabolism [3-5], are associated with infertility [6-9]. Normally in somatic cells, elevated levels of ROS are prevented by the presence of a complex enzymatic antioxidant system involving superoxide dismutase (SOD) that removes $\mathrm{O}_{2}^{--}$and catalase (CAT; restricted to peroxisomes), glutathione peroxidases (GPXs) and peroxiredoxins (PRDXs) that remove $\mathrm{H}_{2} \mathrm{O}_{2}$. GPXs and PRDXs are capable of removing peroxynitrite (formed by the combination of $\mathrm{O}_{2}^{*-}$ and $\mathrm{NO}^{*}$ ). The oxidative stress, a condition resulting of an excessive production of ROS and/or a decrease in the antioxidant defense system [10,11], may cause serious cell injury and even cell death $[11,12]$. In the case of the spermatozoon, the oxidative stress targets all cell components decreasing sperm motility and mitochondrial activity $[13,14]$.

The infertile population has been increasing over the past few decades. However, treatment efficacy is poor because the underlying causes are unknown in 40-50\% of cases [15]. Oxidative stress is a common feature of factors such as environmental pollutants, chemicals, drugs, smoke, toxins, radiation, and diseases related to infertility [16-19]. In such conditions, vital cell components, such as proteins, lipids, and DNA, are oxidized compromising cell function and survival $[11,12]$. ROS-mediated damage to sperm is a significant contributing factor in $30-80 \%$ of infertile men [6-9,20]. The antioxidant system present in semen $[21,22]$ is then not sufficient to protect sperm from ROS-dependent damage such as peroxidation of membrane lipids [23], DNA fragmentation and oxidation of bases [24,25], low mitochondrial membrane potential [26,27] and inactivation of enzymes associated with motility [28,29].

In an era where the artificial reproductive techniques (ARTs), particularly the intracytoplasmic sperm injection (ICSI), are on rising, it is essential to use a safe sperm sample where the DNA integrity is not compromised. Significant sperm DNA oxidation is found in infertile patients and this type of damage has been associated with a wide range of reproductive outcomes from miscarriages to deliver of a live child [7,30,31]. It is worrisome the fact that a spermatozoon with significant DNA damage can be fertilize and even allow embryo development [31-33]. Therefore, it become a priority to perform more studies to gather information on the causes and consequences of oxidative DNA damage to avoid transmitting defects to the child through ARTs such as ICSI.

\section{ROS and male fertility}

The transition from anaerobic to aerobic life came with a cost; the generation of ROS, active species that when produced at high amount promote cell dysfunction or, in extreme cases, cell death [11,12]. However, ROS are beneficial molecules involved in cell signaling [34-37]. This is also true for spermatozoa; low levels of ROS are needed to accomplish capacitation, a process that the 
spermatozoon must undergo in order to achieve fertilizing ability [38-40]. During capacitation, ROS trigger and modulate protein phosphorylation events in a time dependent fashion $[41,42]$.

The presence of antioxidant enzymes is important to maintain low levels of ROS to avoid oxidative damage in spermatozoa [43-45]. Although it is evident that sperm function is regulated by redox signaling, how ROS production and action is modulated for sperm activation is still elusive. Semenogelin and zinc, present in high concentration in the seminal plasma, have been suggested as inhibitors of premature sperm capacitation $[46,47]$. When capacitation takes place, these inhibitors are removed from the spermatozoa to allow a rise of ROS that will trigger the phosphorylation events that ultimate will allow the spermatozoon to achieve the capacitated state [48-50]. However, it is not known how the spermatozoon controls the levels of ROS to avoid the production of an excess of this reactive substances and thus promoting toxicity. Intracellular modulators of ROS production and action are currently unknown; however, a hidden family of antioxidant enzymes called peroxiredoxins (PRDXs) may play a fundamental role in the regulation of ROS action in spermatozoa.

\section{Peroxiredoxins, a new family of enzymes with more than antioxidant activity}

PRDXs are ancestral SH-dependent, selenium- and heme-free peroxidases highly expressed in virtually all living species [51-53]. They are acidic proteins of $\sim 20$ -
$31 \mathrm{kDa}$ with one or two Cys residues at the active site, which are required for their activity [54]. In contrast to GPXs, PRDXs do not require metals ions for their activity [55-57]. They can reduce both organic and inorganic hydroperoxides [58], and peroxynitrite $[59,60]$ by coupling with the thioredoxins (TRX) TRX reductase (TRD) system [53,61,62] (Figure 1). PRDXs are direct targets for $\mathrm{H}_{2} \mathrm{O}_{2}$ due to their $\mathrm{SH}$ and thus are readily oxidized in cells exposed to low $\mathrm{H}_{2} \mathrm{O}_{2}$ levels [63-66]. PRDXs react with $\mathrm{H}_{2} \mathrm{O}_{2}$ as fast as GPXs [66,67]; but PRDXs are known as the dominant peroxide-reducing enzymes in somatic cells [67-69].

PRDXs are regulators of redox signaling $[35,52,70,71]$. The 2-Cys PRDXs are hyperoxidized to sulfinic acid and inactivated by $\mathrm{H}_{2} \mathrm{O}_{2}$ in diverse eukaryotes from yeast to mammals [35,37,52,70,72]. Hyperoxidized PRDXs are reactivated by the sulfinic acid reductases sulfiredoxin (SRX) and sestrins [72-75] (Figure 1). The present hypothesis states that once PRDXs are hyperoxidized, $\mathrm{H}_{2} \mathrm{O}_{2}$ concentration increases allowing the transmission of the signal $[53,62]$. Then, PRDXs are re-activated by SRX and sestrins [72-76] and scavenge $\mathrm{H}_{2} \mathrm{O}_{2}$.

PRDXs are involved in processes such as cell cycle regulation, apoptosis, aging and cancer [77-79]. Animals lacking the PRDX1 gene are tumor prone [80], and their tissues contain elevated levels of damaged DNA [81]. Additionally, cellular senescence is accelerated in $\operatorname{Prdx} 2^{-/-}$mouse embryonic fibroblasts [82]. Spermatozoa from $\mathrm{Prdx}^{-/-}$mice are susceptible to oxidative stress [83]. PRDX4 is present in testis as two isoforms of 27

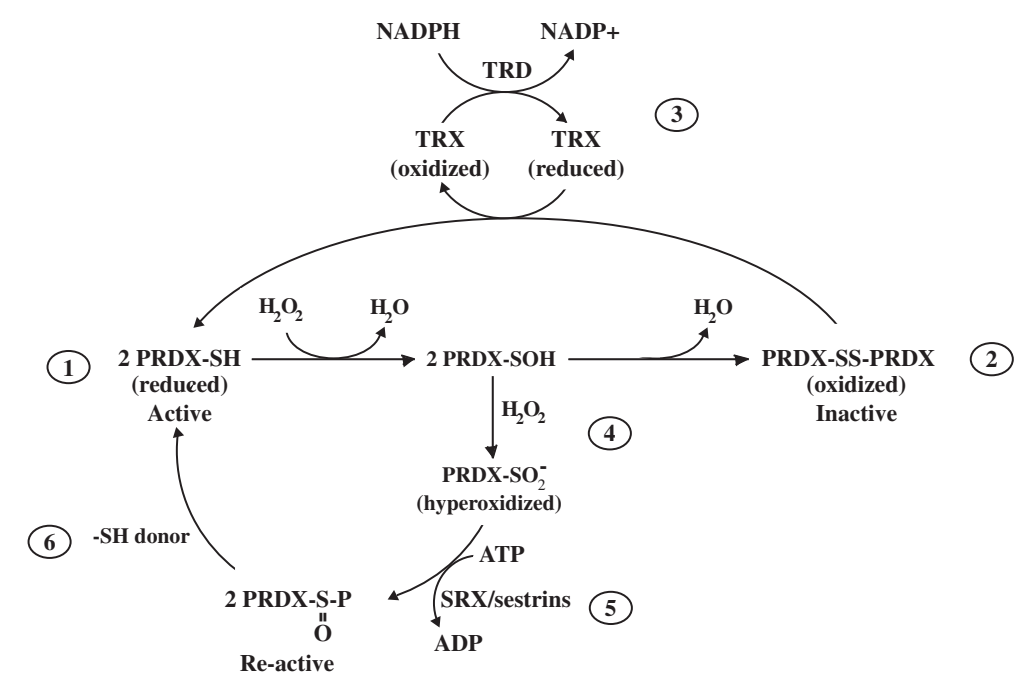

Figure 1 Re-activation of PRDXs. (1) PRDXs scavenge $\mathrm{H}_{2} \mathrm{O}_{2}$ and become oxidized and inactive (2). This inactivation is reversed by the thioredoxin (TRX)-TRX reductase (TRD) system that uses NADPH as reducing equivalents (3). (4) Further thiol oxidation of PRDXs by higher levels of $\mathrm{H}_{2} \mathrm{O}_{2}$ (hyperoxidation) radically inactivates the enzyme allowing $\mathrm{H}_{2} \mathrm{O}_{2}$ levels to increase in the cell and to trigger the $\mathrm{H}_{2} \mathrm{O}_{2}$-dependent signaling. This inactivation must be transient to avoid toxic effects by high levels of $\mathrm{H}_{2} \mathrm{O}_{2}$; thus, after transmission of the signal, $\mathrm{SRX} / \mathrm{sestrins}$ re-activate PRDXs using ATP ( $\mathrm{P}=$ phosphate group) (5). (6) Finally, donors of SH groups such as GSH or TRX, reduce PRDX. 
and $31 \mathrm{kDa}$ [84]; the p27 form is found in the plasma membrane, cytosol and acrosome of human spermatozoa, whereas p31 is found in the head fraction, particularly in the acrosome (Figure 2, Table 1) [85]. The differences in solubility after treatment with detergents such as TritonX-100 (p27 isoform is soluble and p31 insoluble) [85] suggest differences in function; p31 is associated with the formation of the acrosome in the rat [84] and both isoforms are present in the perinucler theca of human spermatozoa [85]. Although the specific role of PRDX4 isoforms in these sperm structures is still unknown, it is possible to speculate that p27 may participate in the regulation of ROS levels and p31 function as a structural protein of the acrosome and perinuclear theca. Noteworthy, PRDX4 appears to have a protective role because mice lacking this isoform have testicular atrophy and increased sperm DNA damage [86].

The major role of PRDXs as $\mathrm{H}_{2} \mathrm{O}_{2}$ scavengers and sensors $[10,35,37]$ is emphasized by their wide sub-cellular distribution (cytosol, nucleus, mitochondria, endoplasmic reticulum and plasma membrane [53,62,95-99]. Our results show that the same situation occurs in human spermatozoa (Figure 2 and Table 1) [85]. PRDXs are differentially distributed in all subcellular compartments of human spermatozoa; remarkably, at least two members of the family are present in each compartment (Table 1) [85]. This striking finding highlights the importance of PRDXs in sperm as major protectors against oxidative stress damage in spermatozoa and potentially key players on the regulation of the local action of ROS to sustain sperm function.

It is worth to mention that PRDX6 is highly abundant and the only member of the family present in all the subcellular compartments of human spermatozoa and to react with $\mathrm{H}_{2} \mathrm{O}_{2}$ at levels that promotes sperm capacitation [85], indicating that PRDX6 might be major player in the regulation of sperm activation.

Traditionally, it is considered that CAT and GPXs are the major if not the unique antioxidant enzymes to protect spermatozoa. This statement was supported by measuring the enzymatic activity by using either $\mathrm{H}_{2} \mathrm{O}_{2}$ (for CAT) or organic hydroperoxides in a reaction with GSH and coupled with glutathione reductase/NAPDPH system to re-cycle the GSSG to GSH (for GPXs). Then, the decay of absorbance due to $\mathrm{H}_{2} \mathrm{O}_{2}$ or NADPH consumption is considered as a measurement of CAT or GPX activities, respectively. Because active PRDXs are present in human spermatozoa $[43,85]$, caution must be taken when these assays are use to determine antioxidant enzymatic activities in these cells. PRDXs can account for the enzymatic activity obtained using these assays as they can use $\mathrm{H}_{2} \mathrm{O}_{2}$ or organic hydroperoxides, NADPH and GSH for their activity. The use of inhibitors such as carmustine (inhibitor of glutathione

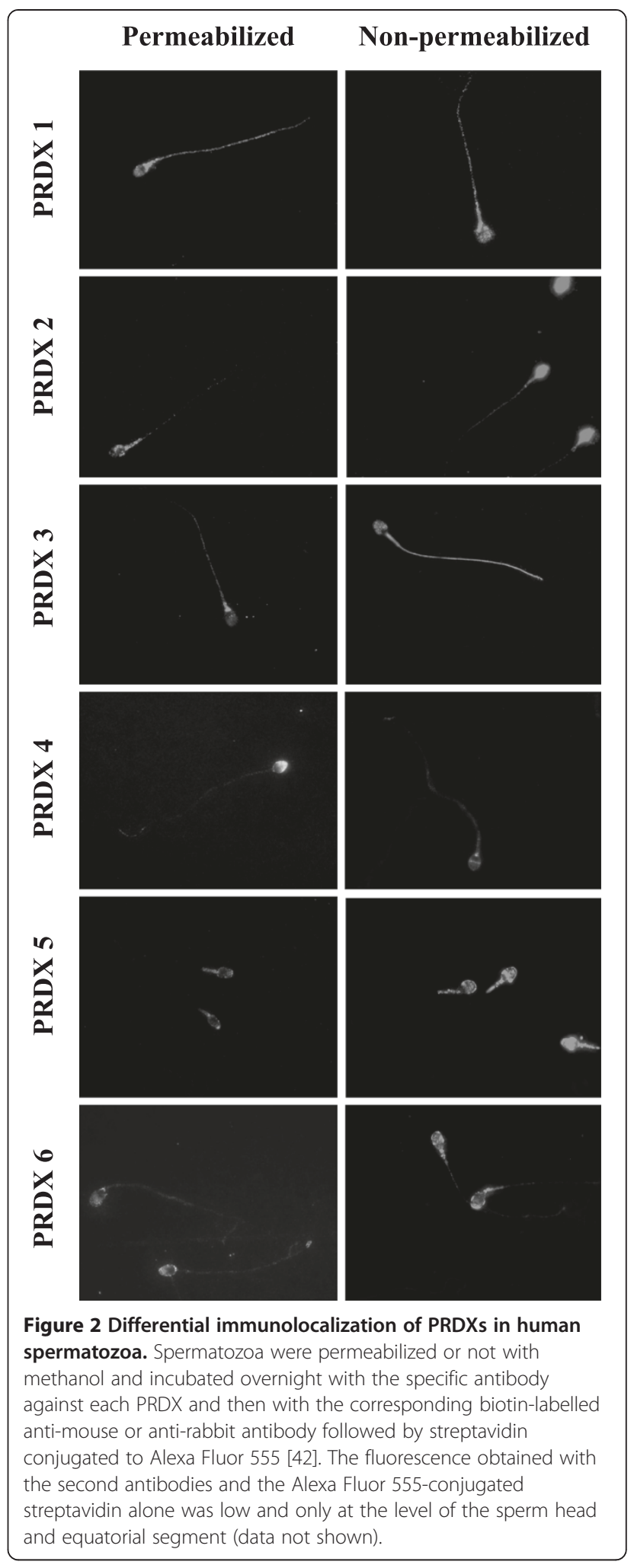

reductase (GRD)) and diethylmaleate (binds to GSH making it non-accessible for GPX/GRD system) are useful to determined specifically PRDX activity [100]. 
Table 1 Distribution of the known antioxidant enzymes in subcellular compartment of human spermatozoa

\begin{tabular}{|c|c|c|c|c|c|c|}
\hline Plasma membrane & Cytosol & Acrosome & Nucleus & Equatorial segment & Midpiece & Flagellum \\
\hline PRDX2 & PRDX4 (p27) & PRDX2 & PRDX1 & PRDX1 & PRDX2 & PRDX1 \\
\hline PRDX4 (p27) & PRDX6 & PRDX4 (p27, p31) & PRDX2 & PRDX5 & PRDX3 & PRDX2 \\
\hline PRDX5 & $\mathrm{Cu} / \mathrm{ZnSOD}$ & PRDX5 & PRDX3 & PRDX6 & PRDX5 & PRDX3 \\
\hline \multirow[t]{8}{*}{ PRDX6 } & TRX1 & PRDX6 & PRDX4 (p27, p31) & TRX1 & PRDX6 & PRDX6 \\
\hline & TRD1 & SPTRX1 & PRDX5 & & MnSOD & SPTRX1 \\
\hline & TGR & SPRTX2 & PRDX6 & & GPX4 (inactive) & SPTRX2 \\
\hline & & TGR & GPX4 (inactive?) & & TRX2 & TRX-like 2 \\
\hline & & & SPRTX1 & & SPTRX1 & TGR \\
\hline & & & SPTRX2 & & SPTRX2 & \\
\hline & & & TRX1 & & TRD2 & \\
\hline & & & TGR & & TGR & \\
\hline
\end{tabular}

References for enzymes listed above: PRDXs [85] and Figure 2, Cu/ZnSOD and MnSOD [87], GPX4 [88,89], SPTRX1 [90-92], SPTRX2 [90,91,93], TRX2 and TRX-like-2 $[91,94]$, TRD1, TRD2 and TGR $[90,91]$.

Based on our findings and on what was explained above, it can be concluded that PRDXs are the first line of defence against $\mathrm{H}_{2} \mathrm{O}_{2}$ and other ROS (hydroperoxides, peroxynitrite) for human spermatozoa because their $\mathrm{H}_{2} \mathrm{O}_{2}$ scavenging capacity [101] (Table 2) does not seem to involve CAT (peroxisomes that contain the enzyme are eliminated from germ cells during spermatogenesis [102], and sodium azide (catalase inhibitor) did not reduce that $\mathrm{H}_{2} \mathrm{O}_{2}$ scavenging capacity (Table 2) or increased the level of sperm lipid peroxidation (Figure 3 )).

Glutathione peroxidase 2, 3 and 5 are not found in human spermatozoa, testes or seminal plasma [104,105] and GPX4 is part of the mitochondrial sheath and it is enzymatically inactive in mature spermatozoa $[88,89,106]$. The role of GPX1 in human sperm is controversial because GPX1 activity was measured using cumene hydroperoxide and NADPH [107], substrates also used by PRDXs. In any case, the participation of GPXs in the antioxidant protection of human spermatozoa might be limited since treatment with diethylmaleate or with carmustine, do not increase the level of lipid peroxidation (Figure 3). Therefore, at least for human spermatozoa, oxidative stress and the associated damage is handled by PRDXs isoforms.

\section{Peroxiredoxins and male infertility}

Human spermatozoa are highly sensitive to ROS $[9,14,108]$. This particularity is due to high content of polyunsaturated

Table 2 Sperm $\mathrm{H}_{2} \mathrm{O}_{2}$ scavenging capacity is not prevented by sodium azide, inhibitor of catalase

\begin{tabular}{ll}
\hline Sperm extract & Units $/ \mathbf{1 0}^{\mathbf{8}}$ spermatozoa \\
Sperm extract $+50 \mu \mathrm{M} \mathrm{NaN}_{3}$ & $2.2 \pm 0.4$ \\
\hline
\end{tabular}

One unit of $\mathrm{H}_{2} \mathrm{O}_{2}$ scavenging capacity is defined as the quantity of spermatozoa capable of decreasing the amount of $\mathrm{H}_{2} \mathrm{O}_{2}$ present in solution by $50 \%$. Results obtained from 3 healthy donors. fatty acids in the plasma membrane, target for extensive oxidation, little cytoplasm and thus low capacity for antioxidant protection by cytoplasmic enzymes (e.g. Cu-Zn SOD) and limited DNA repair mechanisms [22,109-111]. These deficiencies can be worsen if the PRDX system is altered by oxidative stress; because PRDXs are easily oxidized even at low ROS concentration, the presence of an oxidative stress in human spermatozoa will alter the capacity of these enzymes to scavenge excessive amounts of ROS. The necessity for active PRDXs is supported by the data from infertile

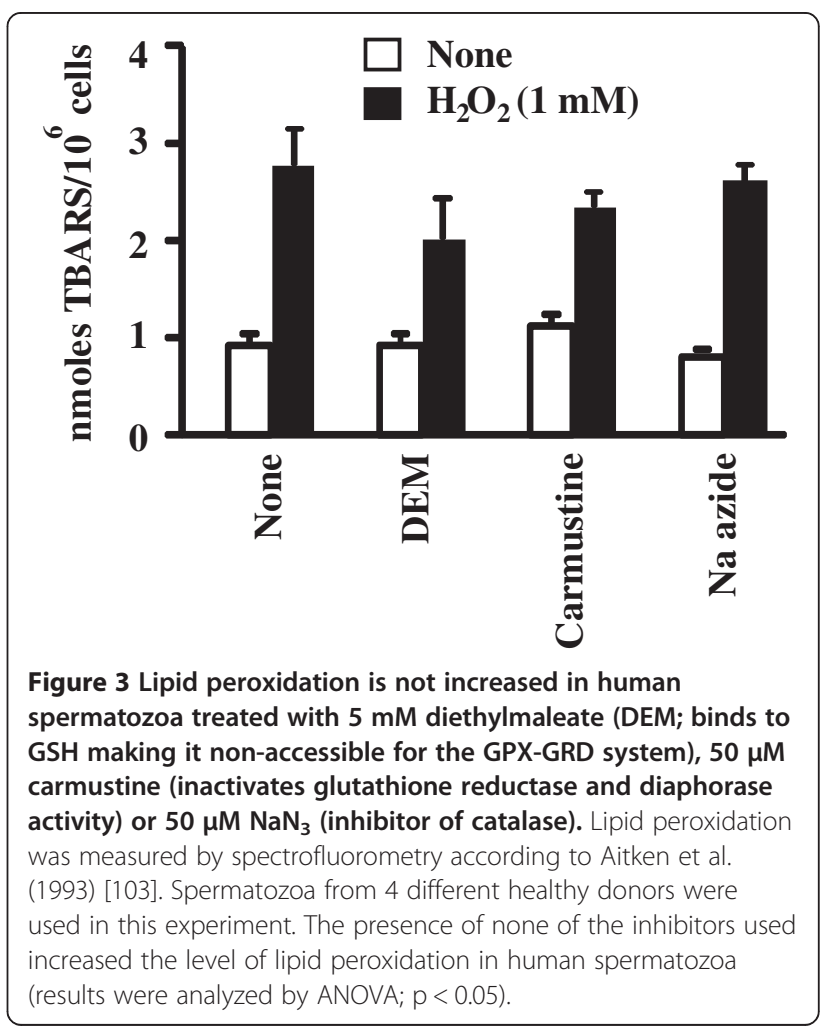


men that have significant lower amounts of PRDXs in both seminal plasma and spermatozoa compared to healthy donors [43]. PRDX6, but not PRDX1, is present in low amounts in seminal plasma of infertile men with clinical varicocele. The total quantity of PRDX1 and PRDX6, but not for PRDX4 and PRDX5, is lower in spermatozoa from varicocele patients (prior to surgery) than in idiopathic infertile men or healthy donors [43]. In terms of PRDXs expression in spermatozoa, the population of infertile men is heterogeneous; sperm PRDX6 was low in 67\% and 39\% varicocele and idiopathic infertile patients, respectively, whereas sperm PRDX1 was only low in $42 \%$ of varicocele patients [43]. Noteworthy, thiol-oxidized PRDX1, PRDX5 and PRDX6 levels were higher in spermatozoa from idiopathic infertile men than from donors [43]. Due to the lower amount of total PRDX1 and PRDX6 and the high thiol oxidation of these PRDXs, very little (less than 20\%) protection due to PRDXs remains and this is associated with impaired sperm motility and poor DNA quality [43].

Interestingly, sperm levels of high molecular mass complexes of hyperoxidized PRDX6 were higher in both infertile men groups than in donors and the PRDX6 thiol oxidation ratio correlated with levels of lipid peroxidation in spermatozoa [43]. From these studies it is evident that thiol oxidation of PRDXs is associated with impairment of sperm function. It is possible that, due to an inability to reduce PRDXs, the levels of ROS rise at toxic levels in the spermatozoon and thus promoting infertility (Figure 4). The potential scenario of failing reactivation of PRDXs is very much plausible in the spermatozoon; the availability of glutathione is minimal in this cell since the level of GSH in human spermatozoa is $\sim 0.3 \mathrm{mM}$ compared to the $10 \mathrm{mM}$ concentration that can be found in somatic cells $[3,112]$. Since GSH is necessary to reduced PRDX6 [113], due to this limitation the reduction of PRDX6 is jeopardized if there is a strong oxidative stress in the spermatozoon and GSH is depleted. The 2-Cys PRDXs can be re-activated by the TRX/TRD system; however, this system is limited by the amount of NADPH present in the cell. In cases of oxidative stress, glucose 6-phosphate dehydrogenase, generator of NADPH, is inactivated and thus the amount of $\mathrm{NADPH}$ is rapidly depleted and in consequence this reducing equivalent is no longer available [114]. Recently, it was reported that aging mice lacking SPTRX1 and SPTRX2 are subfertile [115]. This findings support the need for an intact TRX system to assure fertility. In human spermatozoa, SPTRX1 and SPTRX2 as well as TRX like 2 have been described and their localization is summarized in Table 1. The presence of TRD1 and TRD2

\section{A) Physiological situation}

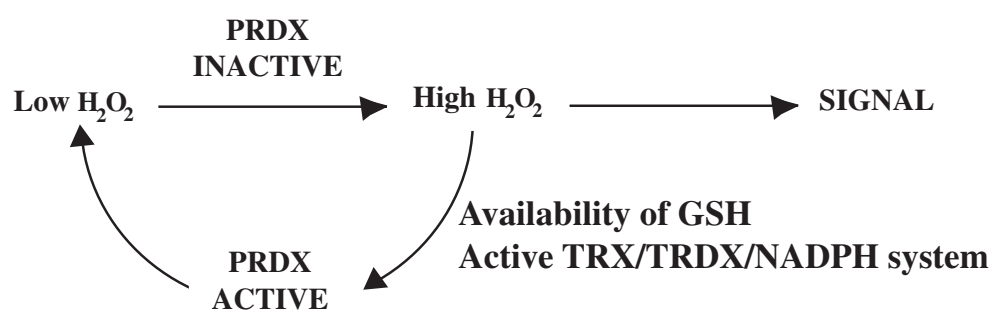

B) Pathological situation

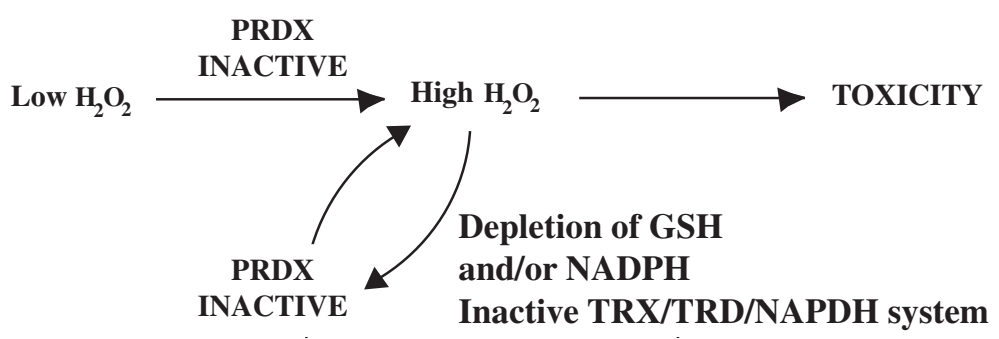

Figure 4 Consequences of PRDXs inactivation in physiological and pathological situations. A) The inactivation of PRDXs due to an increase of $\mathrm{H}_{2} \mathrm{O}_{2}$ occurs in order to allow the signaling for physiological processes. After the signal is triggered, the GSH and NADPH availability and the presence of an active TRX/TRD system allow the re-activation of PRDX to decrease the intracellular level of $\mathrm{H}_{2} \mathrm{O}_{2}$. $\mathbf{B}$ ) Under pathological situations, the already high $\mathrm{H}_{2} \mathrm{O}_{2}$ levels increase even more as the GSH and NAPDH are depleted. Therefore, PRDXs remain inactive and in consequence, the spermatozoon is not protected against the $\mathrm{H}_{2} \mathrm{O}_{2}$-dependent damage on lipids, proteins and DNA. 
(enzymes that reduce the oxidized TRXs including SPTRXs) has been demonstrated by immunoblotting [90], but the exact localization in the sperm cell is still unknown. These studies confirm that a TRX/TRD system is in place in human spermatozoa and more research must be done to better characterize the interaction of PRDXs with this system in the different subcellular compartments of the ejaculated spermatozoon. Another thioredoxins reductase called thioredoxin glutathione reductase (TGR) has been found in human spermatozoa and may be also contributing to the reduction of TRXs [91].The hyperoxidized 2Cys PRDXs can be re-activated by SRX or sestrin with energy consumption [72-75]. Immunohistochemistry studies revealed a moderate staining for SRX (in Sertoli, Leydig and germ cells) and strong staining (mostly in Sertoli and Leydig cells) and moderate for germ cells for sestrin-2 [116]; however, the presence of these enzymes is yet to be confirmed in mature spermatozoa.

Based on what was discussed above, the data presented stress the importance of PRDXs in antioxidant protection of the spermatozoon and offer a possible cause for impaired sperm function in infertile patients. Moreover, the different amounts of PRDXs and their thiol oxidation status in spermatozoa among infertile men may serve the basis for the development of new diagnostic tools.

\section{Antioxidant therapy}

Knowing that the oxidative stress plays a major role in the pathophysiology of male infertility $[7,20,117]$, the antioxidant therapy seems to be the logical strategy to treat those patients. Limited controlled studies, with low number of subjects support the use of antioxidants to treat infertility $[118,119]$. Although in some causes fertility has been improved, in some cases the use of these compounds may harm rather than to help the spermatozoon; for instance the administration of a combination of antioxidants to infertile patients promote a decrease in the DNA compaction and thus exposing the DNA to further damage [120]. There is no doubt that the administration of antioxidant may help infertile patients to achieve fatherhood, but it is essential to know more about the redox signaling is regulated in human spermatozoa to avoid the interference of these compounds on sperm physiology. It is needed a deeper study of what ROS and their levels, and what antioxidant enzymes are impaired in cases of male infertility to design a more 'directed' or 'customized' antioxidant therapy. The use of 'antioxidant cocktails' that is not always beneficial for infertile patients support this re-thinking on how ROS must be controlled in infertile patients.

\section{Conclusions}

The human spermatozoon is extremely sensitive to high levels of ROS. In order to keep in line these active molecules, it should be a very tuned PRDX and TRX/ TRD systems working together in regulating the levels of ROS to avoid impairment of sperm function. Their wide distribution in every compartment of the sperm and the association of low levels and inactivation of them and low sperm quality makes PRDXs a major players in the antioxidant protection and the modulation of ROS action in human spermatozoa.

\section{Abbreviations}

ATP: Adenosine triphosphate; Cys: Cysteine residue; DEM: Diethylmaleate;

DTT: Dithiothreitol; GPX: Glutathione peroxidase; GRD: Glutathione reductase; GSH: Glutathione, reduced form; $\mathrm{H}_{2} \mathrm{O}_{2}$ : Hydrogen peroxide;

MnSOD: Manganese superoxide dismutase (SOD2); NADP+: Nicotinamide adenine dinucleotide phosphate, oxidized form; NADPH: Nicotinamide adenine dinucleotide phosphate, reduced form; $\mathrm{NaN}_{3}$ : Sodium azide; $\mathrm{O}_{2}^{-}$: Superoxide anion; ONOO: Peroxynitrite; PRDX: Peroxiredoxin; ROS: Reactive oxygen species; $\mathrm{SH}$ : Sulfhydryl (thiol) group; $\mathrm{SO}_{2}$ : Sulfinic acid group; Cu/ZnSOD: Cooper/zing superoxide dismutase (SOD1);

SRX: Sulfiredoxin; SS: Disulfide; TBARS: Tiobarbituric acid reactive substances; TRD: Thioredoxin reductase; TRX: Thioredoxin; TGR: Thioredoxin glutathione reductase; SPTRX: Sperm specific thioredoxin.

\section{Competing interests}

No competing interests to declare.

\section{Authors' contribution}

$\mathrm{CO}$ designed and wrote the manuscript.

\section{Authors' information}

$\mathrm{CO}$ is assistant professor at the Department of Surgery, Urology Division, McGill University and medical scientist at the Research Institute, McGill University Health Centre.

\section{Acknowledgments}

I would like to thank the volunteers that donate semen samples for the experiments presented in this review, Ms Shasha Gong for the determination of lipid peroxidation and $\mathrm{H}_{2} \mathrm{O}_{2}$ scavenging capacity studies. This review was supported by the Fonds de Rercherche en Santé Quebec and The Research Institute-McGill University Health Centre.

Other subject areas: Urology, Cell biology, Physiology.

\section{Author details}

${ }^{1}$ The Research Institute of the McGill University Health Centre, Montréal, Québec, Canada. ${ }^{2}$ Department of Surgery (Urology Division), McGill University, Montréal, Québec, Canada. ${ }^{3}$ Department of Obstetrics and Gynecology, McGill University, Montréal, Québec, Canada. ${ }^{4}$ Department of Pharmacology and Therapeutics, McGill University, Montréal, Québec, Canada. ${ }^{5}$ Urology Research Laboratory, Royal Victoria Hospital, room H6.46, 687 Avenue des Pins ouest, Montréal, Québec H3A 1A1, Canada.

Received: 14 November 2013 Accepted: 27 January 2014 Published: 11 February 2014

\section{References}

1. World Health Organization: Towards more objectivity in diagnosis and management of male fertility. Int J Androl 1997, 7(Suppl):1-53.

2. Koppers AJ, De luliis GN, Finnie JM, McLaughlin EA, Aitken RJ: Significance of mitochondrial reactive oxygen species in the generation of oxidative stress in spermatozoa. J Clin Endocrinol Metabol 2008, 93:3199-3207.

3. Halliwell B, Gutteridge J: Antioxidant defences: endogenous and diet derived. In Free Radicals in Biology and Medicine. Edited by Halliwell B, Gutteridge J. New York: Oxford University Press; 2007:79-186.

4. Aitken RJ, Jones KT, Robertson SA: Reactive oxygen species and sperm function-sickness and in health. J Androl 2012, 33:1096-1106.

5. Ferramosca A, Pinto Provenzano S, Montagna DD, Coppola L, Zara V: Oxidative stress negatively affects human sperm mitochondrial respiration. Urology 2013, 82:78-83. 
6. Agarwal A, Gupta S, Sikka S: The role of free radicals and antioxidants in reproduction. Curr Opin Obstet Gynecol 2006, 18:325-332.

7. Aitken RJ, Baker MA: Oxidative stress, sperm survival and fertility control. Mol Cell Endocrinol 2006, 250:66-69.

8. Gagnon C, Iwasaki A, de Lamirande E, Kovalski N: Reactive oxygen species and human spermatozoa. Ann N Y Acad Sci 1991, 637:436-444.

9. de Lamirande $E$, Gagnon C: Impact of reactive oxygen species on spermatozoa: a balancing act between beneficial and detrimental effects. Hum Reprod 1995, 10(Suppl 1):15-21.

10. Halliwell B: Oxidative stress and neurodegeneration: where are we now? J Neurochem 2006, 97:1634-1658.

11. Halliwell B, Gutteridge J: Cellular responses to oxidative stress: adaptation, damage, repair, senescence and death. In Free Radicals in Biology and Medicine. Edited by Halliwell B, Gutteridge J. New York: Oxford University Press; 2007:187-267.

12. Li $Y$, Zhu H, Stansbury KL, Trush MA: Role of reactive oxygen species in multistage carcinogenesis. In Oxygen radicals and the disease process. Edited by Thomas CE, Kalyanaram B. Amsterdam: Academic PRess Publishers; 1997:237-278.

13. Griveau JF, Le Lannou D: Reactive oxygen species and human spermatozoa: physiology and pathology. Int J Androl 1997, 20:61-69.

14. Sikka SC, Rajasekaran M, Hellstrom WJ: Role of oxidative stress and antioxidants in male infertility. J Androl 1995, 16:464-468.

15. de Kretser DM, Baker HWG: Infertility in Men: recent advances and continuing controversies. J Clin Endocrinol Metab 1999, 84:3443-3450.

16. Anderson JB, Williamson RC: Testicular torsion in Bristol: a 25-year review. Br J Surg 1988, 75:988-992.

17. Brennemann W, Stoffel-Wagner B, Helmers A, Mezger J, Jager N, Klingmuller D: Gonadal function of patients treated with cisplatin based chemotherapy for germ cell cancer. J Urol 1997, 158:844-850.

18. Hasegawa M, Wilson G, Russell LD, Meistrich ML: Radiation-induced cell death in the mouse testis: relationship to apoptosis. Radiat Res 1997, 147:457-467.

19. Smith R, Kaune H, Parodi D, Madariaga M, Rios R, Morales I, Castro A: Increased sperm DNA damage in patients with varicocele: relationship with seminal oxidative stress. Hum Reprod 2006, 21:986-993.

20. Tremellen K: Oxidative stress and male infertility: a clinical perspective. Hum Reprod Update 2008, 14:243-258.

21. Lewis SEM, Sterling ES, Young IS, Thompson W: Comparison of individual antioxidants of sperm and seminal plasma in fertile and infertile men. Fertil Steril 1997, 67:142-147.

22. Linschooten JO, Laubenthal J, Cemeli E, Baumgartner A, Anderson D, Sipinen VE, Brunborg G, Haenen GRM, Fthenou E, Briede JJ, van Schooten FJ, Godschalk RWL: Incomplete protection of genetic integrity of mature spermatozoa against oxidative stress. Reproductive Toxicology 2011, 32:106-11.

23. Storey BT: Biochemistry of the induction and prevention of lipoperoxidative damage in human spermatozoa. Mol Hum Reprod 1997, 3:203-213.

24. Aitken RJ, Gordon E, Harkiss D, Twigg JP, Milne P, Jennings Z, Irvine DS: Relative impact of oxidative stress on the functional competence and genomic integrity of human spermatozoa. Biol Reprod 1998, 59:1037-1046.

25. Barroso G, Morshedi M, Oehninger S: Analysis of DNA fragmentation, plasma membrane translocation of phosphatidylserine and oxidative stress in human spermatozoa. Hum Reprod 2000, 15:1338-1344.

26. Piasecka M, Kawiak J: Sperm mitochondria of patients with normal sperm motility and with asthenozoospermia: morphological and functional study. Folia Histochem Cytobiol 2003, 41:125-39.

27. Gallon F, Marchetti C, Jouy N, Marchetti P: The functionality of mitochondria differentiates human spermatozoa with high and low fertilizing capability. Fertil Steril 2006, 86:1526-1530.

28. de Lamirande $\mathrm{E}$, Gagnon C: Reactive oxygen species and human spermatozoa. I. Effects on the motility of intact spermatozoa and on sperm axonemes. J Androl 1992, 13:368-378.

29. de Lamirande E, Gagnon C: Reactive oxygen species and human spermatozoa. II. Depletion of adenosine triphosphate plays an important role in the inhibition of sperm motility. J Androl 1992, 13:379-386.

30. Lewis SE, Aitken RJ: DNA damage to spermatozoa has impacts on fertilization and pregnancy. Cell Tissue Res 2005, 322:33-41.

31. Hansen M, Bower C, Milne E, de Klerk N, Kurinczuk JJ: Assisted reproductive technologies and the risk of birth defects-a systematic review. Hum Reprod 2005, 20:328-338.
32. Marchetti F, Wyrobek AJ: Mechanisms and consequences of paternallytransmitted chromosomal abnormalities. Birth Defects Res C Embryo Today 2005, 75:112-129.

33. Hansen M, Kurinczuk JJ, Bower C, Webb S: The risk of major birth defects after intracytoplasmic sperm injection and in vitro fertilization. $N$ Engl J Med 2002, 346:725-730.

34. Frein D, Schildknecht S, Bachschmid M, Ullrich V: Redox regulation: A new challenge for pharmacology. Biochem Pharmacol 2005, 70:811-823.

35. Rhee SG: Cell signaling. $\mathrm{H}_{2} \mathrm{O}_{2}$, a necessary evil for cell signaling. Science 2006, 312:1882-1883.

36. Rhee SG, Bae YS, Lee SR, Kwon J: Hydrogen peroxide: a Key messenger that modulates protein phosphorylation through cysteine oxidation. SCi STKE 2000, 53:e1

37. Rhee SG, Kang SW, Jeong W, Chang TS, Yang KS, Woo HA: Intracellular messenger function of hydrogen peroxide and its regulation by peroxiredoxins. Curr Opin Cell Biol 2005, 17:183-189.

38. de Lamirande E, Gagnon C: Capacitation-associated production of superoxide anion by human spermatozoa. Free Radic Biol Med 1995, 18:487-495.

39. O'Flaherty C, Beorlegui N, Beconi MT: Participation of superoxide anion in the capacitation of cryopreserved bovine sperm. Int J Androl 2003, 26:109-114.

40. Aitken RJ, Harkiss D, Knox W, Paterson M, Irvine DS: A novel signal transduction cascade in capacitating human spermatozoa characterised by a redox-regulated, CAMP-mediated induction of tyrosine phosphorylation. J Cell Sci 1998, 111(Pt 5):645-656.

41. de Lamirande E, O'Flaherty C: Sperm activation: Role of reactive oxygen species and kinases. Biochim Biophys Acta 2008, 1784:106-115.

42. O'Flaherty C, de Lamirande E, Gagnon C: Positive role of reactive oxygen species in mammalian sperm capacitation: triggering and modulation of phosphorylation events. Free Radic Biol Med 2006, 41:528-540.

43. Gong S, San Gabriel MC, Zini A, Chan P, O'Flaherty C: Low amounts and high thiol oxidation of peroxiredoxins in spermatozoa from infertile Men. J Androl 2012, 33:1342-1351.

44. Smith R, Vantman D, Ponce J, Escobar J, Lissi E: Andrology: Total antioxidant capacity of human seminal plasma. Hum Reprod 1996, 11:1655-1660.

45. Zini A, Fischer MA, Mak V, Phang D, Jarvi K: Catalase-like and superoxide dismutase-like activities in human seminal plasma. Urol Res 2002, 30:321-323.

46. de Lamirande $\mathrm{E}$ : Semenogelin, the main protein of the human semen coagulum, regulates sperm function. Semin Thromb Hemost 2007, 33:60-68.

47. de Lamirande $\mathrm{E}$, Lamothe $\mathrm{G}$ : Levels of semenogelin in human spermatozoa decrease during capacitation: involvement of reactive oxygen species and zinc. Hum Reprod 2010, 25:1619-1630.

48. O'Flaherty C, de Lamirande E, Gagnon C: Phosphorylation of the Arginine-X-X(Serine/Threonine) motif in human sperm proteins during capacitation: modulation and protein kinase A dependency. Mol Hum Reprod 2004, 10:355-363.

49. O'Flaherty $C$, de Lamirande $E$, Gagnon C: Reactive oxygen species and protein kinases modulate the level of phospho-MEK-like proteins during human sperm capacitation. Biol Reprod 2005, 73:94-105.

50. O'Flaherty C, de Lamirande E, Gagnon C: Reactive oxygen species modulate independent protein phosphorylation pathways during human sperm capacitation. Free Radic Biol Med 2006, 40:1045-1055.

51. Hofmann B, Hecht HJ, Flohe L: Peroxiredoxins. Biol Chem 2002, 383:347-364

52. Rhee SG, Chae HZ, Kim K: Peroxiredoxins: a historical overview and speculative preview of novel mechanisms and emerging concepts in cell signaling. Free Radic Biol Med 2005, 38:1543-1552.

53. Wood ZA, Poole LB, Karplus PA: Peroxiredoxin evolution and the regulation of hydrogen peroxide signaling. Science 2003, 300:650-653.

54. Rhee SG, Kang SW, Chang TS, Jeong W, Kim K: Peroxiredoxin, a novel family of peroxidases. IUBMB Life 2001, 52:35-41.

55. Ishii T, Kawane T, Taketani S, Bannai S: Inhibition of the thiol-specific antioxidant activity of rat liver MSP23 protein by hemin. Biochem Biophys Res Commun 1995, 16:970-975.

56. Jin DY, Chae HZ, Rhee $S G$, Jeang KT: Regulatory role for a novel human thioredoxin peroxidase in NF-kappaB activation. J Biol Chem 1997, 272:30952-30961

57. Syed V, Hecht NB: Rat pachytene spermatocytes down-regulate a pololike kinase and up-regulate a thiol-specific antioxidant protein, whereas 
sertoli cells down-regulate a phosphodiesterase and up-regulate an oxidative stress protein after exposure to methoxyethanol and methoxyacetic acid. Endocrinology 1998, 139:3503-3511.

58. Zhang P, Liu B, Kang SW, Seo MS, Rhee SG, Obeid LM: Thioredoxin peroxidase is a novel inhibitor of apoptosis with a mechanism distinct from that of BCl-2. J Biol Chem 1997, 272:30615-30618.

59. Dubuisson M, Vander Stricht D, Clippe A, Etienne F, Nauser T, Kissner R, Koppenol WH, Rees JF, Knoops B: Human peroxiredoxin 5 is a peroxynitrite reductase. FEBS Lett 2004, 571:161-165.

60. Peshenko IV, Shichi H: Oxidation of active center cysteine of bovine 1-Cys peroxiredoxin to the cysteine sulfenic acid form by peroxide and peroxynitrite. Free Radic Biol Med 2001, 31:292-303.

61. Kang SW, Chae HZ, Seo MS, Kim K, Baines IC, Rhee SG: Mammalian peroxiredoxin isoforms can reduce hydrogen peroxide generated in response to growth factors and tumor necrosis factor-alpha. J Biol Chem 1998, 273:6297-6302.

62. Wood ZA, Schröder E, Robin Harris J, Poole LB: Structure, mechanism and regulation of peroxiredoxins. Trends in Biochem Sci 2003, 28:32-40.

63. Baty JW, Hampton MB, Winterbourn CC: Proteomic detection of hydrogen peroxide-sensitive thiol proteins in Jurkat cells. Biochem J 2005, 389:785-795.

64. Cox AG, Hampton MB: BCl-2 over-expression promotes genomic instability by inhibiting apoptosis of cells exposed to hydrogen peroxide. Carcinogenesis 2007, 28:2166-2171.

65. Low FM, Hampton MB, Peskin AV, Winterbourn CC: Peroxiredoxin 2 functions as a noncatalytic scavenger of low-level hydrogen peroxide in the erythrocyte. Blood 2007, 109:2611-2617.

66. Peskin AV, Low FM, Paton LN, Maghzal GJ, Hampton MB, Winterbourn CC: The high reactivity of peroxiredoxin 2 with $\mathrm{H}_{2} \mathrm{O}_{2}$ is Not reflected in its reaction with other oxidants and thiol reagents. J Biol Chem 2007, 282:11885-11892.

67. Winterbourn CC, Hampton MB: Thiol chemistry and specificity in redox signaling. Free Radic Biol Med 2008, 45:549-561.

68. Winterbourn CC: The Biological Chemistry of Hydrogen Peroxide. In Methods in Enzymology Hydrogen Peroxide and Cell Signaling, Part C. Edited by Cadenas E, Packer L. Waltham: Academic Press; 2013:3-25.

69. Karplus P, Poole L: Peroxiredoxins as molecular triage agents, sacrificing themselves to enhance cell survival during a peroxide attack. Mol Cell 2012, 45:275-278.

70. Fourquet $\mathrm{S}$, Huang ME, D'Autreaux B, Toledano MB: The dual functions of thiol-based peroxidases in $\mathrm{H}_{2} \mathrm{O}_{2}$ scavenging and signaling. Antioxid Redox Signal 2008, 10:1565-1576.

71. Kang SW, Rhee SG, Chang TS, Jeong W, Choi MH: 2-Cys peroxiredoxin function in intracellular signal transduction: therapeutic implications. Trends Mol Med 2005, 11:571-578.

72. Woo HA, Kang SW, Kim HK, Yang KS, Chae HZ, Rhee SG: Reversible oxidation of the active site cysteine of peroxiredoxins to cysteine sulfinic acid. Immunoblot detection with antibodies specific for the hyperoxidized cysteine-containing sequence. J Biol Chem 2003, 278:47361-47364.

73. Biteau B, Labarre J, Toledano MB: ATP-dependent reduction of cysteinesulphinic acid by S. cerevisiae sulphiredoxin. Nature 2003, 425:980-984.

74. Budanov AV, Sablina AA, Feinstein E, Koonin EV, Chumakov PM: Regeneration of Peroxiredoxins by p53-Regulated Sestrins, Homologs of Bacterial AhpD. Science 2004, 304:596-600.

75. Jonsson TJ, Johnson LC, Lowther WT: Structure of the sulphiredoxinperoxiredoxin complex reveals an essential repair embrace. Nature 2008 , 451:98-101.

76. Chae HZ, Kang SW, Rhee SG: Isoforms of mammalian peroxiredoxin that reduce peroxides in presence of thioredoxin. In Methods in Enzymology Oxidants and Antioxidants Part B. Edited by Lester P. San Diego: Academic Press; 1999:219--226.

77. Smith-Pearson PS, Kooshki M, Spitz DR, Poole LB, Zhao W, Robbins ME: Decreasing peroxiredoxin II expression decreases glutathione, alters cell cycle distribution, and sensitizes glioma cells to ionizing radiation and $\mathrm{H}_{2} \mathrm{O}_{2}$. Free Radic Biol Med 2008, 8:1178-1189.

78. Immenschuh S, Baumgart-Vogt E: Peroxiredoxins, oxidative stress, and cell proliferation. Antiox Redox Signal 2005, 7:768-777.

79. Kropotov A, Gogvadze V, Shupliakov O, Tomilin N, Serikov VB, Tomilin NV Zhivotovsky B: Peroxiredoxin V is essential for protection against apoptosis in human lung carcinoma cells. Exp Cell Res 2006, 312:2806-2815.

80. Neumann CA, Krause DS, Carman CV, Das S, Dubey DP, Abraham JL, Bronson RT, Fujiwara Y, Orkin SH, Van Etten RA: Essential role for the peroxiredoxin Prdx1 in erythrocyte antioxidant defence and tumour suppression. Nature 2003, 424:561-565.

81. Egler RA, Fernandes E, Rothermund K, Sereika S, de Souza-Pinto N, Jaruga P, Dizdaroglu M, Prochownik EV: Regulation of reactive oxygen species, DNA damage, and c-Myc function by peroxiredoxin 1. Oncogene 2005, 24:8038-8050

82. Han YH, Kim HS, Kim JM, Kim SK, Yu DY, Moon EY: Inhibitory role of peroxiredoxin II (Prx II) on cellular senescence. FEBS Lett 2005, 579:4897-4902.

83. Ozkosem B, O'Flaherty C: Detrimental effects of oxidative stress on spermatozoa lacking peroxiredoxin 6. Free Radic Biol Med 2012, 53:S86.

84. Sasagawa I, Matsuki S, Suzuki Y, luchi Y, Tohya K, Kimura M, Nakada T, Fujii J: Possible involvement of the membrane-bound form of peroxiredoxin 4 in acrosome formation during spermiogenesis of rats. Eur J Biochem 2001, 268:3053-3061.

85. O'Flaherty C, de Souza AR: Hydrogen peroxide modifies human sperm peroxiredoxins in a dose-dependent manner. Biol Reprod 2011, 84:238-247.

86. Iuchi Y, Okada F, Tsunoda S, Kibe N, Shirasawa N, Ikawa M, Okabe M, Ikeda $Y$, Fujii J: Peroxiredoxin 4 knockout results in elevated spermatogenic cell death via oxidative stress. Biochem J 2009, 419:149-158.

87. Mennella MR, Jones R: Properties of spermatozoal superoxide dismutase and lack of involvement of superoxides in metal-ion-catalysed lipidperoxidation and reactions in semen. Biochem J 1980, 191:289-297.

88. Schneider M, Forster $H$, Boersma A, Seiler A, Wehnes $H$, Sinowatz F, Neumuller C, Deutsch MJ, Walch A, Hrabe De Angelis M, Wurst W, Ursini F, Roveri A, Maleszewski M, Maiorino M, Conrad M: Mitochondrial glutathione peroxidase 4 disruption causes male infertility. FASEB J 2009, 23:3233-3242

89. Ursini F, Heim S, Kiess M, Maiorino M, Roveri A, Wissing J, Flohe L: Dual function of the selenoprotein PHGPx during sperm maturation. Science 1999, 285:1393-1396.

90. Miranda-Vizuete A, Ljung J, Damdimopoulos AE, Gustafsson J, Oko R, Pelto-Huikko M, Spyrou G: Characterization of sptrx, a novel member of the thioredoxin family specifically expressed in human spermatozoa. J Biol Chem 2001, 276:31567-31574.

91. Miranda-Vizuete A, Sadek CM, Jimenez A, Krause WJ, Sutovsky P, Oko R: The mammalian testis-specific thioredoxin system. Antiox Redox Signal 2004, 6:25-40.

92. Yu Y, Oko R, Miranda-Vizuete A: Developmental expression of spermatidspecific thioredoxin-1 protein: transient association to the longitudinal columns of the fibrous sheath during sperm tail formation. Biol Reprod 2002, 67:1546-1554

93. Miranda-Vizuete A, Tsang K, Yu Y, Jimenez A, Pelto-Huikko M, Flickinger CJ, Sutovsky P, Oko R: Cloning and developmental analysis of murid spermatid-specific thioredoxin-2 (SPTRX-2), a novel sperm fibrous sheath protein and autoantigen. J Biol Chem 2003, 278:44874-44885.

94. Sadek CM, Jimenez A, Damdimopoulos AE, Kieselbach T, Nord M, Gustafsson J, Spyrou G, Davis EC, Oko R, van der Hoorn FA, Miranda-Vizuete A: Characterization of Human Thioredoxin-like 2: A novel microtubule-binding thioredoxin expressed predominantly in the cilia of lung airway epithelium and spermatid and spermatid manchette and axoneme. J Biol Chem 2003, 278:13133-13142

95. Banmeyer I, Marchand C, Verhaeghe C, Vucic B, Rees JF, Knoops B: Overexpression of human peroxiredoxin 5 in subcellular compartments of chinese hamster ovary cells: effects on cytotoxicity and DNA damage caused by peroxides. Free Radic Biol Med 2004, 36:65-77.

96. Immenschuh S, Baumgart-Vogt E, Tan M, Iwahara S, Ramadori G, Fahimi HD: Differential cellular and subcellular localization of heme-binding protein 23/peroxiredoxin I and heme oxygenase-1 in Rat liver. J Histochem Cytochem 2003, 51:1621-1631.

97. Oberley TD, Verwiebe E, Zhong W, Kang SW, Rhee SG: Localization of the thioredoxin system in normal rat kidney. Free Radic Biol Med 2001, 30:412-424

98. Seo MS, Kang SW, Kim K, Baines IC, Lee TH, Rhee SG: Identification of a new type of mammalian peroxiredoxin that forms an intramolecular disulfide as a reaction intermediate. J Biol Chem 2000, 275:20346-20354

99. Thannickal VJ, Fanburg BL: Reactive oxygen species in cell signaling. Am J Physiol Lung Cell Mol Physiol 2000, 279:L1005-L1028.

100. Manandhar G, Miranda-Vizuete A, Pedrajas JR, Krause WJ, Zimmerman S, Sutovsky M, Sutovsky P: Peroxiredoxin 2 and peroxidase enzymatic activity of mammalian spermatozoa. Biol Reprod 2009, 80:1168-1177. 
101. Zini A, de Lamirande E, Gagnon C: Reactive oxygen species in semen of infertile patients: levels of superoxide dismutase- and catalase-like activities in seminal plasma and spermatozoa. Int J Androl 1993, 16:183-188.

102. Nenicu A, Luers GH, Kovacs W, Bergmann M, Baumgart-Vogt E: Peroxisomes in human and mouse testis: differential expression of peroxisomal proteins in germ cells and distinct somatic cell types of the testis. Biol Reprod 2007, 77:1060-1072.

103. Aitken RJ, Harkiss D, Buckingham D: Relationship between iron-catalysed lipid peroxidation potential and human sperm function. J Reprod Fertil 1993, 98:257-265

104. Chabory E, Damon C, Lenoir A, Henry-Berger J, Vernet P, Cadet R, Saez F, Drevet JR: Mammalian glutathione peroxidases control acquisition and maintenance of spermatozoa integrity. J Anim Sci 2009, 88:1321-1331.

105. Williams K, Frayne J, Hall L: Expression of extracellular glutathione peroxidase type 5 (GPX5) in the rat male reproductive tract. Mol Hum Reprod 1998, 4:841-848.

106. Foresta C, Flohe L, Garolla A, Roveri A, Ursini F, Maiorino M: Male fertility is linked to the selenoprotein phospholipid hydroperoxide glutathione peroxidase. Biol Reprod 2002, 67:967-971.

107. Garrido N, Meseguer M, Alvarez J, Simon C, Pellicer A, Remohi J: Relationship among standard semen parameters, glutathione peroxidase/glutathione reductase activity, and mRNA expression and reduced glutathione content in ejaculated spermatozoa from fertile and infertile men. Fertil Steril 2004, 82(Suppl 3):1059-1066.

108. Aitken RJ: Free radicals, lipid peroxidation and sperm function. Reprod Fertil Dev 1995, 7:659-668.

109. Alvarez JG, Aitken RJ: Lipid Peroxidation in Human Spermatozoa. In Studies on Men's Health and Fertility. Edited by Agarwal A, Aitken RJ, Alvarez JG. New York: Humana Press; 2012:119-130.

110. Aitken RJ, Buckingham DW, Carreras A, Stewart Irvine D: Superoxide dismutase in human sperm suspensions: relationship with cellular composition, oxidative stress, and sperm function. Free Radic Biol Med 1996, 21:495-504.

111. Smith TB, Dun MD, Smith ND, Curry BJ, Connaughton HS, Aitken RJ: The presence of a truncated base excision repair pathway in human spermatozoa that is mediated by OGG1. J Cell Sci 2013, 126:1488-1497.

112. Li T: The glutathione and thiol content of mammalian spermatozoa and seminal plasma. Biol Reprod 1975, 12:641-646.

113. Manevich Y, Fisher AB: Peroxiredoxin 6, a 1-Cys peroxiredoxin, functions in antioxidant defense and lung phospholipid metabolism. Free Radic Biol Med 2005, 38:1422-1432.

114. Griveau JF, Dumont E, Renard P, Callegari JP, Le Lannou D: Reactive oxygen species, lipid peroxidation and enzymatic defence systems in human spermatozoa. J Reprod Fertil 1995, 103:17-26.

115. Smith TB, Baker MA, Connaughton HS, Habenicht U, Aitken RJ: Functional deletion of Txndc2 and Txndc3 increases the susceptibility of spermatozoa to age-related oxidative stress. Free Radic Biol Med 2013, 65:872-881.

116. Uhlen $M$, Bjorling $E$, Agaton C, Szigyarto CAK, Amini B, Andersen $E$, Andersson AC, Angelidou P, Asplund A, Asplund C, Berglund L, Bergstrom K, Brumer H, Cerjan D, Ekstrom M, Elobeid A, Eriksson C, Fagerberg L, Falk R, Fall J, et al: A human protein atlas for normal and cancer tissues based on antibody proteomics. Mol Cell Proteom 2005, 4:1920-1932.

117. Agarwal A, Makker K, Sharma R: Clinical relevance of oxidative stress in male factor infertility: an update. Am J Reprod Immunol 2008, 59:2-11.

118. Showell MG, Brown J, Yazdani A, Stankiewicz MT, Hart RJ: Antioxidants for male subfertility. Cochrane Database Syst Rev 2011, 1:1-102.

119. Gharagozloo P, Aitken RJ: The role of sperm oxidative stress in male infertility and the significance of oral antioxidant therapy. Hum Reprod 2011, 26:1628-1640.

120. Menezo YJR, Hazout A, Panteix G, Robert F, Rollet J, Cohen-Bacrie P, Chapuis F, Clement P, Benkhalifa M: Antioxidants to reduce sperm DNA fragmentation: an unexpected adverse effect. Reprod BioMed Online 2007, 14:418-421.

\section{doi:10.1186/2051-4190-24-4}

Cite this article as: O'Flaherty: Peroxiredoxins: hidden players in the antioxidant defence of human spermatozoa. Basic and Clinical Andrology 2014 24:4.

\section{Submit your next manuscript to BioMed Central and take full advantage of:}

- Convenient online submission

- Thorough peer review

- No space constraints or color figure charges

- Immediate publication on acceptance

- Inclusion in PubMed, CAS, Scopus and Google Scholar

- Research which is freely available for redistribution 